\title{
Influence of beer and wort sample freezing on the result of analysis
}

\author{
Karel Štěrba*, Pavel Čejka, Jana Olšovská \\ Research Institute of Brewing and Malting, Plc., \\ Lípová 15, 12000 Prague, Czech Republic
}

*corresponding author: sterba@beerresearch.cz

\begin{abstract}
Freezing is a common way of storing samples including beer samples. To verify the suitability of this procedure, the results of determination of alcohol (\% v/v), original gravity, color, $\mathrm{pH}$, thiobarbituric acid index, total polyphenols, saccharides, limit of attenuation, free amino nitrogen, protein nitrogen by coomassie brilliant blue, iso- $\alpha$-bitter acids, diacetyl, higher alcohols, esters, fatty acids, carbonyl compounds and hop oils in beer, and protein nitrogen by coomassie brilliant blue and total polyphenols in wort were compared before and after freezing the sample. It was found that most determinations were not affected by sample freezing, but the determinations of alcohol, original gravity and total polyphenols were affected. In case these very frequent determinations would need to be performed after freezing, a new uncertainty of the method was calculated for these analyzes. From the spectrum of fifteen tested carbonyl compounds, there was a statistically significant increase in the concentration of four compounds (2-methylpropanal, 2-methylbutanal, 3-methylbutanal, phenylacetaldehyde). A significant decrease after sample freezing was
\end{abstract} observed for most of the analyzed essential oils.

Keywords: beer analysis, sample stability, sample freezing

\section{Introduction}

In a brewery, control chemical analyzes are performed immediately after sampling. Sometimes, however, the situation requires a longer delay between sampling and analysis, especially, if it is special analysis that is not performed by the brewery laboratory and the sample must be sent for analysis elsewhere, or if it is impossible for operational reasons (personnel problems, failure of the measuring instrument). In this case, proper storage of the sample before analysis is crucial, as it must be ensured that its physicochemical properties do not change and that a value relevant to the original sample is obtained after analysis. The stability of a stored sample is not only related to wort or other intermediate of beer production, whose chemical composition changes rapidly, but finished beer is also concerned. Often it occurs that analyzes must be performed from the last opened package or from a sample of draft beer, etc. Then it is important to know how to handle such a sample and whether the storage conditions will not change it.
The first option is to cool the sample to temperatures near $0{ }^{\circ} \mathrm{C}$. However, this may not be sufficient in many cases, as oxygen easily enters the sample stored in this way, which promotes a number of undesirable reactions. In addition, light-assisted reactions or bacterial contamination with subsequent secondary fermentation may occur.

Freezing the sample and storing it in the dark seems to be ideal storing conditions. Focus on whether freezing a sample can change the results of analyzes is found especially in clinical biochemistry and laboratory diagnostics. Lee et al. (2015) found that repeated freezing a blood plasma sample affects the content of some types of proteins. Similar results were obtained by Cuhadar et al. (2013), who found that glucose, cholesterol, lipoproteins and HDL (high density lipoprotein), among others, were stable during storage of frozen samples, while the changes of the content of total protein, albu- 
min and calcium were statistically significant. Changes in calcium content during freezing blood serum, sweat and urine samples were also observed by Omang and Velar (1974), who recommended shaking the sample thoroughly before analysis because the samples split into several layers during melting.

Only a small number of such studies have been published in food analysis. For example the effect of freezing on nitrite, nitrate, phosphate and silicate content in seawater samples was studied (Dore et al., 1996). The effect of freezing on protein and lipid content in breast milk was also studied (Vieira et al., 2011).

However, a complete study of the stability of analytes in brewing matrices during the "freeze-thaw" process has not been performed yet. In case of beer, in terms of freezing, attention was paid only to the formation of haze. Skinner et al. (1993) found that frozen beer haze contains mainly $\beta$-glucans and dextrins, the protein content is highly variable, and the polyphenol content is low.

Therefore, the aim of this study was to verify whether the sample freezing can be used for selected analyzes of wort and beer as a possible method of storage before analysis itself.

\section{Material and Methods}

\subsection{Samples}

Samples of pale lagers purchased from a local store were used for beer analyzes. Samples of wort were prepared in a pilot brewery of Research Institute of Brewing and Malting by a two-mash decoction procedure, all worts brewed with an extract $12 \%$, bitterness 47 IBU.

\subsection{Sample preparation}

The beer sample was shaken for 20 minutes on a shaker at a room temperature in a vessel equipped with a perforated cap. The sample was then divided into two parts - the first part was immediately analyzed, the second part was placed in a Teflon sample box with a narrow neck, the sample box was closed, the cap secured with a parafilm and the sample was stored for 4 weeks at $-18^{\circ} \mathrm{C}$ (except for the determination of limit of attenuation which was stored for only 2 weeks). After thawing, the samples were mixed thoroughly and analyzes were repeated.

Samples of freshly brewed wort were divided into two parts and further processed in the same way as beer samples.

\subsection{Sample analysis}

Sample analyzes were performed according to the methodologies listed in Table 1.
The content of essential oils was determined by the modified methodology MEBAK 2.23.6 Determination of steam-volatile aroma compounds in beer. One hundred milliliters of beer with the addition of $500 \mu \mathrm{L}$ of internal standard cis-3-heptenol at a concentration of $100 \mathrm{mg} / \mathrm{L}$ was distilled off with steam on a Büchi distillation apparatus. The distillate was collected in a $250 \mathrm{~mL}$ volumetric flask containing $10 \mathrm{~mL}$ of a 1:1 hexane-dichloromethane mixture placed in an ice-water bath. After the completion of the distillation, the sample was shaken on an orbital shaker (250 rpm) for 1 hour. After shaking, the sample was placed in a refrigerator for at least 1 hour to separate phases. The organic layer was collected for analysis. The determination was performed on a Thermo Ultra gas chromatograph with a DSQ II mass spectrometer. The chromatographic column used was TG-WAXMS (Thermo), $30 \mathrm{~m}$ length, $0.25 \mathrm{~mm}$ inner diameter and $0.25 \mu \mathrm{m}$ film thickness. The column was tempered to $45{ }^{\circ} \mathrm{C}$ and this temperature was maintained for 2 minutes after the injection. This was followed by a temperature gradient of $8{ }^{\circ} \mathrm{C} / \mathrm{min}$ to $130{ }^{\circ} \mathrm{C}$ and then immediately by another gradient of $15^{\circ} \mathrm{C} / \mathrm{min}$ to $230^{\circ} \mathrm{C}$, where the temperature was maintained for 5 minutes. The carrier gas flow (He, purity 5.0) was $1.2 \mathrm{~mL} / \mathrm{min}$. One microliter of the sample was injected in a splitless mode, 1 min after the injection the split was opened at a flow rate of $50 \mathrm{~mL} / \mathrm{min}$. The temperature of the injector and the transfer line to the mass spectrometer was $250^{\circ} \mathrm{C}$.

\subsection{Evaluation of results}

The differences between fresh and frozen samples were tested using a paired t-test in the Statistica 12 program, which was used to determine whether the differences found within the results were statistically significant. The result of the paired test marked with * means a difference at the probability level of $95 \%$, the result marked with ** means the difference at the probability level of $99 \%$, the result marked with ${ }^{* * *}$ means the difference at the probability level of $99.9 \%$.

The difference between the results before and after freezing the sample was also compared to the uncertainty of the method.

To determine whether freezing affects the analysis result, the paired t-test was evaluated and at the same time the average and maximum difference between the results were compared to the uncertainty of the method. In this way, four possibilities can arise:

- the paired test showed a difference, and such a difference between results was higher than the uncertainty of the method - the difference was significant, and freezing of the sample affects the result of analysis; 
Table 1 Overview of used analytical methods

\begin{tabular}{|c|c|c|c|}
\hline Analysis & Reference & Uncertainty of determination & $\begin{array}{l}\text { Number and type } \\
\text { of compared samples }\end{array}$ \\
\hline Alcohol & EBC 9.2.6 & $0.05 \% \mathrm{v} / \mathrm{v}$ & 9 beers \\
\hline Original gravity & EBC 9.4 & $0.06 \% \mathrm{w} / \mathrm{w}$ & 9 beers \\
\hline Beer bitterness & EBC 9.8 & $1.0 \mathrm{IBU}$ & 3 beers \\
\hline Color of beer & EBC 9.6 & $0.5 \mathrm{EBC}$ & 3 beers \\
\hline $\mathrm{pH}$ of beer & EBC 9.35 & 0.04 & 3 beers \\
\hline Thiobarbituric acid index & MEBAK 2.4 & 3 & 3 beers \\
\hline Total polyphenols & EBC 9.11 & $8 \mathrm{mg} / \mathrm{L}$ & 3 beers, 3 worts \\
\hline Carbohydrate determination & EBC 8.7; Jurková et al., 2014 & $10 \%$ & 3 beers \\
\hline Limit of attenuation & EBC 8.6.1; EBC 9.7 & $0.8 \%$ & 3 beers \\
\hline Free amino nitrogen & Basařová et al., 1993 & $15 \%$ & 3 beers \\
\hline $\begin{array}{c}\text { Protein nitrogen } \\
\text { by coomassie brilliant blue }\end{array}$ & Škach et al., 1985 & $1 \mathrm{mg} / 100 \mathrm{~mL}$ & 3 beers, 3 worts \\
\hline Iso- $a$-bitter acids & Jurková et al., 2003 & $20 \%$ & 3 beers \\
\hline Diacetyl & EBC 9.24.2 & $0.025 \mathrm{mg} / \mathrm{L}$ & 3 beers \\
\hline Alcohols and esters & EBC 9.39; Horák et al., 2009 & $\begin{array}{l}15 \%^{\mathrm{a}} \\
25 \%^{\mathrm{b}} \\
30 \%^{\mathrm{c}}\end{array}$ & 3 beers \\
\hline Fatty acids & Horák et al., 2013 & $\begin{array}{l}15 \% \text { short chain fatty acids } \\
20 \% \text { long chain fatty acids }\end{array}$ & 3 beers \\
\hline Carbonyl compounds & Čejka et al., 2013 & $25 \%$ & 3 beers \\
\hline Hop oils & MEBAK 2.23.6 (2013) mod. & $25 \%$ & 3 beers \\
\hline
\end{tabular}

a uncertainty for ethyl acetate, 2-methylpropyl acetate, 3-methylbutyl acetate, ethylhexanoate, 2-phenylethyl acetate, ethylhexanol, ethyl octanoate, ethyl decanoate, n-propanol, 2-methylpropanol, 2- and 3-methylbutanol, 2-phenylethanol

${ }^{b}$ uncertainty for acetaldehyde

c uncertainty for ethyl formate, propyl acetate, ethyl butyrate, butyl acetate, ethyl 2-hydroxypropanoate, ethyl dodecanoate, ethyl tetra decanoate, ethyl hexadecanoate, furfuryl alcohol

d chain length up to 10 carbons

- the paired test showed a difference, but the difference between results was lower than the uncertainty of the method - the difference was decided on the basis of the absolute size of the difference between the results, i.e. freezing is unlikely to affect the result of analysis;

- the paired test did not show a difference, but the difference between results was higher than the uncertainty of the method - the difference was decided on the basis of the absolute size of the difference in the results, i.e. freezing is likely to affect the result of analysis;

- the paired test did not show a difference, and the difference between results was lower than the uncertainty of the method - freezing of the sample does not affect the result of analysis.

\section{Results and discussion}

The results of the comparison of basic analyzes before and after freezing are summarized in Table 2. The table shows that $\mathrm{pH}$, color, bitterness, total concentra- tion of free amino nitrogen (FAN), iso- $\alpha$-bitter acids and diacetyl are not affected by freezing. For these methods, no difference in the results before and after freezing was found by the paired t-test, as well as the difference between the results did not exceed the uncertainty of the method.

Conversely, the difference in the results of the determination of the original gravity and alcohol content was proved by the paired t-test. The concentration of the extract after freezing was decreased, on average by 0.09 , by a maximum even by $0.13 \% \mathrm{w} / \mathrm{w}$, which considerably exceeds the uncertainty of determination of $0.06 \% \mathrm{w} / \mathrm{w}$. For alcohol determination, the difference is marginal. The average value of the difference (decrease) was 0.04 , and the maximum value $0.06 \% \mathrm{v} / \mathrm{v}$. The uncertainty of the method is $0.05 \% \mathrm{v} / \mathrm{v}$, so the average value fits into the uncertainty, whereas the maximum value not. Due to the result of the paired test, this marginal error cannot be neglected. The decrease in alcohol content probably occurred due to the evaporation of a small but significant amount of ethanol during stor- 
Table 2 Comparison of results of fresh and frozen beer samples - basic analyzes

\begin{tabular}{|c|c|c|c|c|}
\hline Analysis & Paired t-test $t^{a}$ & Average difference & Maximum difference & $\begin{array}{l}\text { Freezing the sample } \\
\text { recommendation }\end{array}$ \\
\hline Alcohol (\% v/v) & $* * *$ & 0.04 (decrease) & 0.06 & No \\
\hline OG $(\% w / w)$ & $* * *$ & 0.09 (decrease) & 0.13 & No \\
\hline $\mathrm{pH}$ & & 0.01 (decrease) & 0.08 & Yes \\
\hline Color (EBC) & & 0.1 (increase) & 0.3 & Yes \\
\hline Biterness (IBU) & & 0.03 (increase) & 0.65 & Yes \\
\hline Limit of attenuation (\%) & $* * *$ & 0.7 (decrease) & 0.8 & Yes \\
\hline Total polyphenols (mg/L) & & 8 (decrease) & 12 & No \\
\hline $\mathrm{CBB}(\mathrm{mg} / 100 \mathrm{~mL})$ & * & 0.7 (increase) & 0.9 & Yes \\
\hline TBA & $* *$ & 1 (increase) & 1 & Yes \\
\hline FAN (mg/L) & & 1.3 (decrease) & 4 & Yes \\
\hline Iso-a-bitter acids (mg/L) & & 1.9 (decrease) & 4 & Yes \\
\hline Diacetyl (mg/L) & & 0.001 (decrease) & 0.006 & Yes \\
\hline
\end{tabular}

${ }^{a}$ see 2.4 Evaluation of results

age. This is also related to the decrease in the original gravity. When substituting the decrease in alcohol content into the Balling formula,

$$
O G=\frac{100 \times\left(2.0665 A+\mathrm{E}_{\mathrm{S}}\right)}{100+1.0665 A}
$$

$\mathrm{OG}$ - extract of the original wort $(\% \mathrm{w} / \mathrm{w})$

A - alcohol content in beer $(\% \mathrm{w} / \mathrm{w})$

$E_{S}-$ real beer extract $(\% \mathrm{w} / \mathrm{w})$

the average decrease in OG of $0.06 \% \mathrm{w} / \mathrm{w}$ and the maximum decrease of $0.10 \% \mathrm{w} / \mathrm{w}$ is obtained. This does not explain the whole found decrease, but the remaining difference of $0.03 \% \mathrm{w} / \mathrm{w}$ may already be caused by the inherent uncertainty of the determination.

Due to the frequency and importance of determining the alcohol content and the original gravity, a correction of the result after freezing was determined to obtain the correct value. After the comparison of the results before and after freezing the sample, a correlation relationship

$$
\mathrm{A}_{\text {corig }}=1.01 \times \mathrm{A}_{\text {freez }}
$$

$A_{\text {corig }}$ - corrected alcohol content $(\% \mathrm{v} / \mathrm{v})$

$\mathrm{A}_{\text {freez }}$ - measured alcohol content after freezing (\% v/v)

is obtained. Using this conversion, a corrected alcoholic content is obtained which is close to the original value measured in the fresh sample. However, this way, additional uncertainty is introduced into the determination due to freezing the sample and necessary manipulations associated with the process itself. To determine the new uncertainty of the determination, it is necessary to combine the original uncertainty of the determination with the uncertainty involving freezing and thawing of the sample. From the differences in the results of analyzes of the fresh sample and the frozen one after correction, the standard deviation is calculated and used in equation

$$
S_{\text {total }}=\sqrt[2]{\mathrm{s}^{2}{ }_{\text {orig }}+\mathrm{s}^{2}{ }_{\text {dif }}}
$$

$\mathrm{s}_{\text {total }}$ - new standard deviation of the determination

$\mathrm{s}_{\text {orig }}$ - standard deviation of the original determination (one half of the original uncertainty of the method)

$\mathrm{s}_{\text {dif }}$ - standard deviation of differences between analyzes of fresh sample and the frozen one after correction

The new uncertainty of determination is then obtained as twice the $s_{\text {total }}$, which is $0.06 \% \mathrm{v} / \mathrm{v}$ (original uncertainty is $0.05 \% \mathrm{v} / \mathrm{v}$ ).

To calculate the original gravity, the corrected alcohol content in $\% \mathrm{w} / \mathrm{w}$ was calculated, which was then substituted into the Balling formula. For the obtained corrected values, a new uncertainty of determination was calculated analogously to the previous procedure, for freezing the sample it was increased to $0.08 \% \mathrm{w} / \mathrm{w}$ (original uncertainty is $0.06 \% \mathrm{w} / \mathrm{w}$ ).

The determinations of limit of attenuation, total polyphenols, protein nitrogen by coomassie brilliant blue (CBB) and thiobarbituric acid index (TBA) have marginal results, either a difference was proved by the paired 
t-test or the difference between samples before and after freezing was higher than the uncertainty of the method. For TBA, limit of attenuation and CBB, the paired t-test showed a difference, but the maximum difference between samples was lower than the method uncertainty in all determinations, so it can be assumed that freezing the sample will not affect the analysis result.

Conversely, for the determination of total polyphenols, the maximum difference $(12 \mathrm{mg} / \mathrm{L})$ and the average difference $(8 \mathrm{mg} / \mathrm{L})$ between samples were greater than or equal to the uncertainty of the method $(8 \mathrm{mg} / \mathrm{L})$, therefore although no difference was proved by the paired t-test, it is assumed that freezing would affect the result of analysis. The decrease in the content of polyphenols can be caused by their depolymerization, to a lesser extent their oxidation cannot be excluded.

At the same time, the effect of freezing on the determination of total polyphenols and CBB in wort was monitored. As can be seen from Table 3, a similar difference (decrease) was observed for the total polyphenols content between the samples as it was for beer, in addition, the paired t-test proved a difference. Similarly, for CBB, the difference between the results before and after freezing was again statistically demonstrated, but when compared to beer, a higher difference than the uncertainty of the determination was found. Therefore, freezing of wort is not recommended in any of these analyzes.

When determining the total polyphenols in a sample, a correction can also be made to obtain correct results. As no correlation was found between the decrease in total polyphenols concentration during freezing and their original content, but all differences were similar (see Tables 2 and 3), the adjustment of the results consists in adding the average difference before and after freezing, i.e. $8 \mathrm{mg} / \mathrm{L}$. The change in the uncertainty of the method is calculated in the same way as for the alcohol and the original gravity, the new uncertainty is $11 \mathrm{mg} / \mathrm{L}$.

The comparison of the determination of sugars, carbohydrates, fatty acids, alcohols, and esters did not show the influence of sample freezing on the analysis result (see Table 4).

An interesting result was obtained in the determination of carbonyl compounds (see Table 5). While no effect of freezing was observed for most of the tested compounds, a difference was found for 2-methylpropanal, 2-methylbutanal, 3-methylbutanal and phenylacetaldehyde. Said carbonyls are mainly formed by Strecker degradation of amino acids, the course of which is significantly influenced by the presence of oxygen (Vanderhaegen et al., 2006). Thus, it is likely that these oxidation reactions caused an increase in the concentration of the given carbonyls after freezing. To confirm whether the samples for the determination of these carbonyl compounds can be frozen, it is necessary to verify how their concentration changes during storage and whether the reason for their increased content could be the prolonged storage time (1 month).

When comparing the content of hop essential oils before and after freezing of the sample, a significant decrease of the monitored essential oils was found. Their total amount was 20 to $50 \%$ lower after freezing, but, for example, the myrcene content decreased by 60 to $80 \%$.

Table 3 Comparison of results of fresh and frozen wort samples

\begin{tabular}{|c|c|c|c|c|}
\hline Analysis & Paired t-test $^{\mathrm{a}}$ & Average difference & Maximum difference & $\begin{array}{c}\text { Freezing the sample } \\
\text { recommendation }\end{array}$ \\
\hline Total polyphenols $(\mathrm{mg} / \mathrm{L})$ & ${ }^{*}$ & 8.3 (decrease) & 10 & No \\
\hline $\mathrm{CBB}(\mathrm{mg} / 100 \mathrm{~mL})$ & ${ }^{*}$ & 5.1 (increase) & 7.1 & No \\
\hline
\end{tabular}

${ }^{a}$ see 2.4 Evaluation of results

Table 4 Comparison of results of fresh and frozen beer samples - carbohydrates, fatty acids, alcohols and esters

\begin{tabular}{|c|c|c|c|c|}
\hline Analysis & Paired t-test ${ }^{2}$ & Average difference & Maximum difference & $\begin{array}{c}\text { Freezing the sample } \\
\text { recommendation }\end{array}$ \\
\hline Sugars $(\mathrm{g} / 100 \mathrm{~mL})$ & & 0.01 (decrease) & 0.02 & Yes \\
\hline Carbohydrates $(\mathrm{g} / 100 \mathrm{~mL})$ & & 0.05 (increase) & 0.1 & Yes \\
\hline Sum of alcohols $(\mathrm{mg} / \mathrm{L})$ & & 3.53 (increase) & 3.89 & Yes \\
\hline Sum of esters $(\mathrm{mg} / \mathrm{L})$ & & 0.35 (decrease) & 1.94 & Yes \\
\hline Sum of short chain fatty acids $(\mathrm{mg} / \mathrm{L})$ & & 0.23 (decrease) & 0.54 & Yes \\
\hline Sum of long chain fatty acids $(\mathrm{mg} / \mathrm{L})$ & & 0.09 (decrease) & 0.27 & Yes \\
\hline
\end{tabular}

${ }^{a}$ see 2.4 Evaluation of results 
Table 5 Comparison of results of fresh and frozen beer samples - carbonyl compounds

\begin{tabular}{|c|c|c|c|c|}
\hline Analyte & Paired t-test $t^{a}$ & $\begin{array}{l}\text { Average difference } \\
(\mu \mathrm{g} / \mathrm{L})\end{array}$ & $\begin{array}{l}\text { Maximum difference } \\
\qquad(\mu \mathrm{g} / \mathrm{L})\end{array}$ & $\begin{array}{l}\text { Freezing the sample } \\
\text { recommendation }\end{array}$ \\
\hline Acetaldehyde & & 235 (increase) & 1114 & Yes \\
\hline Acetone & & 37 (increase) & 73 & Yes \\
\hline 2-Methylpropanal & $* *$ & 2.00 (increase) & 2.30 & No \\
\hline 3-Methylbut-2-on & & 0.14 (decrease) & 0.41 & Yes \\
\hline 2-Methylbutanal & * & 1.50 (increase) & 1.95 & No \\
\hline 3-Methylbutanal & * & 3.30 (increase) & 4.10 & No \\
\hline Trans-2-butenal & & 0.15 (decrease) & 0.34 & Yes \\
\hline Hexanal & & 0.41 (increase) & 0.77 & Yes \\
\hline Heptanal & & 0.13 (increase) & 0.20 & Yes \\
\hline Octanal & & 0.10 (decrease) & 0.66 & Yes \\
\hline Furan-2-carbaldehyde & & 0.19 (increase) & 1.56 & Yes \\
\hline Benzaldehyde & & 1.80 (increase) & 2.70 & Yes \\
\hline Phenylacetaldehyde & $* *$ & 4.60 (increase) & 5.20 & No \\
\hline 2-Butanone & & 0.59 (increase) & 0.93 & Yes \\
\hline
\end{tabular}

${ }^{a}$ see 2.4 Evaluation of results

The reason may be chemical changes during storage (especially access to oxygen), possible sorption on the walls of the sample box in which the sample was stored, or evaporation of more volatile essential oils (myrcene) during thawing of the sample. These phenomena have been described at higher temperatures by Peacock and Deinzer (Peacock and Deinzer, 1988).

\section{Conclusion}

The study has shown that in some cases freezing of beer or wort samples before analysis is not suitable for sample storage. In analyzes of alcohol and the original gravity, there may be a decrease in the concentration that exceeds the uncertainty of the method. If, due to the circumstances, freezing is the only option, higher uncertainty of the method must be taken into account. Freezing the sample before analysis of essential oils in beer is completely inappropriate as there is a large percentage loss of all essential oils (20 to $50 \%$ ), with myrcene even by $60-80 \%$. Minor changes also occur in the determination of limit of attenuation, protein nitrogen by coomassie brilliant blue, total polyphenols and carbonyl compounds. For the other monitored determinations $(\mathrm{pH}$, color, bitterness, thiobarbituric acid index, free amino nitrogen, iso- $\alpha$-bitter acids, diacetyl, alcohols, esters, fatty acids and carbohydrates) the influence of sample freezing on the analysis result wasn't proved.

\section{Acknowledgment}

This study was supported by institutional support No. MZE-R01918 of the Ministry of Agriculture of the Czech Republic.

\section{References}

Basařová G. et al.: 6.8.5 Stanovení nízkomolekulárních dusíkatých látek (volného aminodusíku): 6.8.5.2 Metoda TNBS, in Pivovarsko-sladařská analytika 2, 1993, Merkanta s.r.o., Praha. Available only in Czech.

Cuhadar, S., Koseoglu, M., Atay, A., Dirican, A., 2013: The effect of storage time and freeze-thaw cycles on the stability of serum samples. Biochemia Medica 23(1): 70-77. https://doi.org/10.11613/ BM.2013.009

Čejka, P.; Čulík, J.; Horák, T.; Jurková, M.; Olšovská, J., 2013: Use of chemical indicators of beer aging for ex-post checking of storage conditions and prediction of the sensory stability of beer. J. Agric. Food Chem. 61(51): 12670-12675. https://doi.org/10.1021/jf403361h

Dore, J.E., Houlihan, T., Hebel, D.V., Tien, G., Tupas, L., Karl, D.M., 1996: Freezing as a method of sample preservation for the analysis of dissolved inorganic nutrients in seawater. Marine Chem. 53(3-4): 173185. https://doi.org/10.1016/0304-4203(96)00004-7

EBC 8.6.1 (2002): Fermentability, attenuation limit of wort reference fermentation, in Analytica EBC, ed. EBC Analysis Committee-Nürnberg, Hans Carl Getränke Fachverlag, Chap. 8.6.1.

EBC 8.7 (2004): Fermentable carbohydrates in wort by HPLC (IM), in Analytica EBC, ed. EBC Analysis Committee-Nürnberg, Hans Carl Getränke Fachverlag, Chap. 8.7.

EBC 9.2.6 (2008): Alcohol in beer by near infrared spectroscopy, in Analytica EBC, ed. EBC Analysis Committee-Nürnberg, Hans Carl Getränke Fachverlag, Chap. 9.2.6.

EBC 9.4 (2004): Original, real and apparent extract and original gravity of beer, in Analytica EBC, ed. EBC Analysis Committee-Nürnberg, Hans Carl Getränke Fachverlag, Chap. 9.4. 
EBC 9.6 (2000): Colour of beer: Spectrophotometric method (IM), in Analytica EBC, ed. EBC Analysis Committee-Nürnberg, Hans Carl Getränke Fachverlag, Chap. 9.6.

EBC 9.7 (2000): Final attenuation of beer, in Analytica EBC, ed. EBC Analysis Committee-Nürnberg, Hans Carl Getränke Fachverlag, Chap. 9.7.

EBC 9.8 (2004): Bitterness of beer (IM), in Analytica EBC, ed. EBC Analysis Committee-Nürnberg, Hans Carl Getränke Fachverlag, Chap. 9.8.

EBC 9.11 (2002): Total polyphenols in beer by spectrophotometry (IM), in Analytica EBC, ed. EBC Analysis Committee-Nürnberg, Hans Carl Getränke Fachverlag, Chap. 9.11.

EBC 9.24.2 (1999): Vicinal diketones in beer: Gas chromatographic method, in Analytica EBC, ed. EBC Analysis Committee-Nürnberg, Hans Carl Getränke Fachverlag, Chap. 9.24.2.

EBC 9.35 (2004): pH of beer, in Analytica EBC, ed. EBC Analysis Committee-Nürnberg, Hans Carl Getränke Fachverlag, Chap. 9.35.

EBC 9.39 (2000): Dimethyl sulphide and other lower boiling point volatile compounds in beer by gas chromatography, in Analytica EBC, ed. EBC Analysis Committee-Nürnberg, Hans Carl Getränke Fachverlag, Chap. 9.39.

Horák, T.; Čulík, J.; Jurková, M.; Čejka, P.; Kellner, V.; Dvořák, J.; Hašková, D., 2009: Faster gas chromatography and its use in brewing. Part 2. - The determination of high volatile beer flavours after headspace extraction. Kvasný Průmysl 55(10): 268-272. https://doi. org/10.18832/kp2009022

Horák, T.; Čulík, J.; Jurková, M.; Čejka, P.; Olšovská, J., 2013 Determination of fatty acids in beer by fast routine analyse. Kvasný Průmysl 59(3): 58-62. https://doi.org/10.18832/kp2013006

Jurková, M., Kellner, V., Čulík, J., Horák, T., Čejka, P., 2003: Effective and easy isolation of iso-alpha acids from beer by SPE method. Kvasný Průmysl 49(9): 258-259. https://doi.org/10.18832/kp2003016. Available only in Czech.

Jurková J., Štěrba K., Čejka P., Olšovská J., 2014: Determination of Total Carbohydrate Content in Beer Using Its Pre-column Enzymatic Cleavage and HPLC-RI. Food Anal. Methods 7: 1677-1686. https:// doi.org/10.1007/s12161-014-9805-y
Lee, J.-E., Kim, S.Y., Shin, S.-Y., 2015: Effect of repeated freezing and thawing on biomarker stability in plasma and serum samples. Osong Public Health Res. Perspect. 6(6): 357-362. https://doi.org/10.1016/j. phrp.2015.11.005

MEBAK 2.4 Thiobarbituric acid index, in MEBAK Wort, Beer, Beer-based beverages, 2013, Freising-Weihenstephan, Germany, ISBN: 978-39805814-7-9.

MEBAK 2.23.6 Determination of steam-volatile aroma compounds in beer, in MEBAK Wort, Beer, Beer-based beverages, 2013, Freising-Weihenstephan, Germany, ISBN: 978-3-9805814-7-9.

Omang, S.H., Velar, O.D., 1974: Concentration gradients in biological samples during storage, freezing and thawing. Fresenius J. Anal. Chem. 269: 177-181. https://doi.org/10.1007/BF00424310

Peacock, V.E., Deinzer, M.L., 1988: Fate of hop oil components in beer. J. Am. Soc. Brew. Chem. 46(4): 104-107. https://doi.org/10.1094/ASBCJ-46-0104

Skinner, K.E., Hardwick, B.C., Saha, R.B., 1993: Characterization of frozen beer precipitates from single packages. J. Am. Soc. Brew. Chem. 51(2): 58-62. https://doi.org/10.1094/ASBCJ-51-0058

Škach, J., Zimová, I., Mikyška, A.: Modernizace analytické kontroly v pivovarském průmyslu, Výzkumná zpráva VÚPS, Praha, 1985. Available only in Czech.

Vanderhaegen, B., Neven, H., Verachtert, H., Derdelinckx, G., 2006: The chemistry of beer aging - a critical review. Food Chem. 95(3): 357381. https://doi.org/10.1016/j.foodchem.2005.01.006

Vieira, A.A., Soares, F.V.M., Pimenta, H.P., Abranches, A.D., Moreira, M.E.L., 2011: Analysis of the influence of pasteurization, freezing/thawing, and offer processes on human milk's macronutrient concentrations. Early Hum. Dev. 87(8): 577-580. https://doi.org/10.1016/j.earlhumdev.2011.04.016 